\title{
Floral Biology and Behavior of Africanized Honeybees Apis mellifera in Soybean (Glycine max L. Merril)
}

\author{
Wainer César Chiari ${ }^{1}$, Vagner de Alencar Arnaut de Toledo ${ }^{1 *}$, Maria Claudia Colla \\ Ruvolo-Takasusuki ${ }^{2}$, Valeria Maria Attencia ${ }^{1}$, Fabiana Martins Costa ${ }^{1}$, Carolina Satie \\ Kotaka $^{1}$, Eduardo Shiguero Sakaguti ${ }^{1}$ and Helida Regina Magalhães ${ }^{1}$ \\ ${ }^{I}$ Departmento de Zootecnia; ${ }^{2}$ Departmento de Biologia Celular e Genética; Universidade Estadual de Maringá; Av. \\ Colombo,5790; vaatoledo@uem.br; 87020-900; Maringá - PR - Brazil
}

\begin{abstract}
This research was carried out to evaluate the pollination by Africanized honeybees Apis mellifera, the floral biology and to observe the hoarding behavior in the soybean flowers (Glycine max Merril), var. BRS-133. The treatments were constituted of demarcated areas for free visitation of insects, covered areas by cages with a honeybee colony (A. mellifera) and also covered areas by cage without insects visitation. All areas had $24 \mathrm{~m}^{2}$ (4m $x$ 6m). The soybean flowers stayed open for a larger time $(82.82 \pm 3.48$ hours) in covered area without honeybees. The stigma of the flowers was also more receptive $(P=0.0021)$ in covered area without honeybees $(87.3 \pm 33.0 \%)$ and at 10:42 o'clock was the schedule of greater receptivity. The pollen stayed viable in all treatments, the average was $99.60 \pm 0.02 \%$, which did not present differences among treatments. The percentage of abortion of the flowers was $82.91 \%$ in covered area without honeybees, this result was superior $(P=0.0002)$ to the $52.66 \%$ and $53.95 \%$ of the treatments uncovered and covered with honeybees, respectively. Honeybees were responsible for $87.7 \%$ of the pollination accomplished by the insects. The medium amounts of total sugar and glucose measured in the nectar of the flowers were, $14.33 \pm 0.96 \mathrm{mg} /$ flower and $3.61 \pm 0.36 \mathrm{mg} /$ flower, respectively, not showing differences $(P<0.05)$ among the treatments. The total solids, measured through the manual refratometer were $21.33 \pm 0.22 \%$ in uncovered area and $22.33 \pm 0.38 \%$ in covered with honeybees and differed to each other $(P=0.0001)$. The honeybees were the most frequent insect (95.18\%). Other observed insects were the Lepidoptera with $3.51 \%$ and other bees with $1.32 \%$, in uncovered area. Honeybees visited 2.24 flowers on average in uncovered area and 1.58 in covered with honeybees and presented behavior for nectar hoarding and hoarding nectar/pollen in this period. In uncovered area the time of nectar hoarding was $2.55 \pm 0.07$ seconds, this time was smaller $(P=0.0039)$ than $2.87 \pm 0.08$ seconds observed in covered area with honeybees. The behavior for the hoarding type observed in honeybees foraging the soybean flowers, through the content of its honey stomach and pollen loads of its pollen basket showed that the nectar forager did not show a pattern for the nectar collection, but for the pollen collection the schedule of pollen peak of the forager was at 11:36 o'clock. The soybean flowers showed alteration in floral biology when exposed to honeybees.
\end{abstract}

Key words: Africanized honeybee, Apis mellifera, soybean, Glycine max, pollination, floral biology, honeybee behavior

\footnotetext{
${ }^{*}$ Author for correspondence
} 


\section{INTRODUCTION}

Soybean (Glycine $\max$ L. Merril) is one of the most cultivated grains in the entire world. The United States is the largest world producer and obtained an estimated income of US\$ $16,490,700,000.00$ in 1998 and the estimated benefit through the pollination made by the honeybees Apis mellifera L. was US\$ $824,500,000.00$ to the farmers (Morse and Calderone, 2000). Brazil is the second largest produce of soybean and in 2000 was 31.746 .420 tons (IBGE, 2000). Production in Parana State in 2000/2001 was 8.294 millions tons (Embrapa, 2001). The flower type is raceme, it can present from 1 to 35 white or purple blossoms one plant can present until 800 flowers, but the pods production is from 13 to $57 \%$ of this total (Shaik and Probst, 1958). A large number of flowers do not produce seeds and the abortions index can exceed $75 \%$ in some varieties (Free, 1993). The blossoms present the characteristics and the form of the majority of the papilionoideae legumen: presence of standard petal in keel which protects the stamen (Fig. 1).

The calyx is relatively big in proportion to the flower size or in relation to the other legume calyx. Each flower is capable to produce one pod. Some varieties stop growing when the flowering starts which remains from 4 to 6 weeks. It is possible to find half million of flowers in half hectare with soybean culture (McGregor, 1976).

The flowers present a nectar-defined guide, consisting of convergent lines to the nectary entrance. These guides are visible in the varieties that present flowers with different purple tonalities, and absent in the white varieties (Erickson and Garment, 1979).

In the USA central region, the nectar production and the visits made by the honeybees in soybean flowers happened between $9 \mathrm{~h} 00$ and $15 \mathrm{~h} 00$ of each day. The peak of this activity and the time that the flowers kept opened changed with the varieties and the local conditions. The nectar quantity per flower, higher in hot weather, fluctuated significantly among the varieties from 0.2 to $0.5 \mu \mathrm{L}$. The total sugar content in the nectar varied from 37 to $45 \%$, being that the flower sugar concentration increased and the volume decreased with the time and the temperature. It was not observed any difference in the carbohydrates tenors between the varieties with white and purple flowers (Erickson, 1984).

Robacker et al (1982), studying soybean flowers attractiveness to honeybees, reported that several environmental factors affected the attractiveness through the effects on the flowers characteristics. In general, there was influence of the daily temperature. Plants which grew up in elevated temperature were twice more attractive, than the ones which grew up in low temperatures with maximum of $29^{\circ} \mathrm{C}$.



Figure 1 -Soybean blossom longitudinal section (adapted from McGregor, 1976). 
In other experiment carried out by Severson and Erickson (1984) where the same parameters were observed in Haiti, the most significant difference happened in the production rate of nectar/flower, which varied from 0.22 to $0.127 \mu \mathrm{L}$ between the varieties.

The honeybees forage in the soybean seeking for nectar and pollen. The honeybee population can exceed the density of one honeybee per linear meter in the collection peak. Other 29 bee species, besides A. mellifera, were found foraging in the soybean in three regions of USA (Erickson, 1984). The pollen collection by the honeybees is related with the capacity of the variety to produce it. Little pollen can be collected in some areas, meanwhile, more than $50 \%$ of the total quantity of pollen collected by some colonies can provide from the soybean (Free, 1993).

Soybean flower structure assures to the $A$. mellifera honeybees the forage, favoring the pollen transfer (Erickson and Garment, 1979). Other authors like Morse and Cartter (1937), Rubis (1970) e Wolff (2000) consider soybean as autogamic and the auto pollination guaranties good productivity to the farmers, without necessity of insects to realize the pollination. Jaycox (1970) observed that the A. mellifera visited soybean flowers as to the pollen collect, as to nectar. However, the quantity of produced nectar by each flower was small, but the flower density was high and the culture areas were generally big, making it a good food source. Erickson (1975) observed that it was necessary to consider that the soybean flowers attraction exercised on the honeybees reported attraction levels in different varieties. According to Mason (1979), the honeybees did not show preference between purple or white flowers. Piper and Morse (1923) observed that soybean flowers were visited by the honeybees and also observed that three varieties in Jackson, Tennessee-USA, where the flowering presented smells that reminded the smells of the violets and they were more attractive to the honeybees.

The objective of this work was to study the soybean (G. max) floral biology variety BRS-133 and evaluate the $A$. mellifera Africanized honeybees behavior in these flowers.

\section{MATERIAL AND METHODS}

The experiment was carried out at Fazenda Experimental de Iguatemi (FEI) of Universidade Estadual de Maringá (UEM), where 15 hectares of soybean were established (variety BRS-133). In this area, pollination cages were installed, made with nylon screen (two mm), supported by PVC tubes $(1 / 4$ inch), forming cages in a semi-arch with four meters wide, six meters length and two $\mathrm{m}$ high, covering an area of $24 \mathrm{~m}^{2}$ (Fig. 2). Soybean plantation was realized in November $18^{\text {th }}$ in 2000 and the harvested 122 days after the plantation. The culture was monitored during all the period with particular attention during the flowering that started on January $15^{\text {th }}$ in 2001.

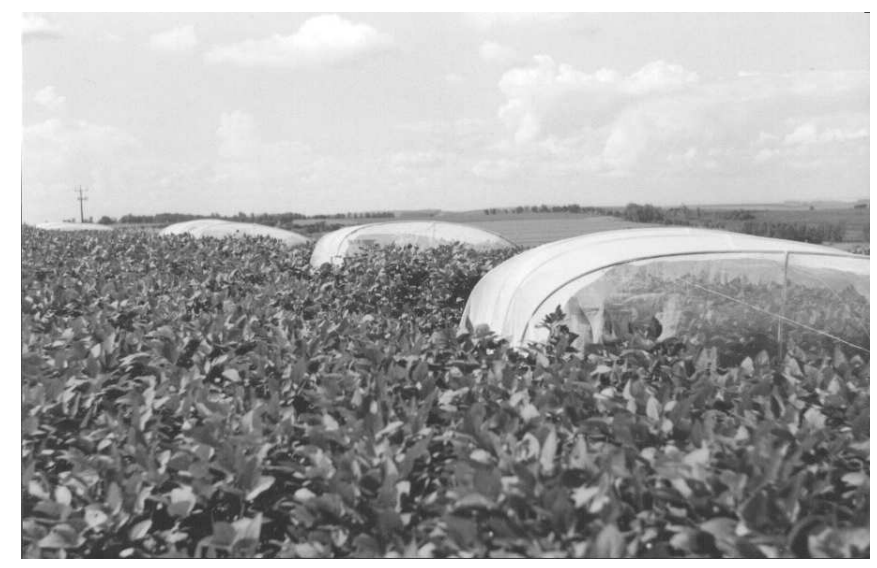

Figure 2 -Model of pollination cage used in the experiment measuring $4 \mathrm{~m}$ x $6 \mathrm{~m}$. 
The treatments consisted of (a)- free treatment, compounded by five areas with $24 \mathrm{~m}^{2}$ each, marked with colored ribbon; (b)- treatment covered with honeybees, compounded by five pollination cages, covering the same area of the previous treatment, containing inside it an $A$. mellifera honeybee colony, with five frames and (c)- covered treatment without honeybees, covering $24 \mathrm{~m}^{2}$. The areas were marked at random in the soybean culture and the cages were mounted immediately before the beginning of the flowers opening 14/01/2001 and dismounted 31/01/2001, when the last flowers withered.

In all repetitions of the treatments, 100 flower buds were marked at random with numbered labels. These buds were observed periodically, since the opening till the flowers withering and this time was considered as anthesis.

The stigma receptivity to the pollen grains was evaluated in five flowers collected at each two hours (from $0700 \mathrm{~h}$ until $1700 \mathrm{~h}$ ), for five days during the flowering, from $18-24 / 01 / 2001$, in the three treatments. According to King (1960), the peroxidase enzyme presence reflects the stigma receptivity. The flowers were dived in oxygenated water (20 volumes) after the style extracted and the air bubbles detached of the stigma was observed and recorded in scores that varied from zero to non-receptive, one to moderate receptivity to two, high receptivity.

To verify of the pollen grains viability in the flowering period, five flowers from each treatment were collected at each two hours (from 0700h until $1500 \mathrm{~h}$ ), for three days. Five hundred pollen grains were analyzed in each lamina, following the Radford et al (1974) technique, mentioned by Vitali and Letizio-Machado (1995). The viability was also verified in the pollen grains found with the visiting agent, extracting the pollen grains and their corbicula and colored through the same technique. To verify the honeybee fidelity to soybean flower, it was used the method described by Toledo (1997).

The abortion percentage in soybean flowers was measured through the counting of all buds of five plants marked with ribbons in different colors, in each parcel of the three treatments. In the harvest, the pods of each plant were collected, calculating thus the aborted flowers percentage. The quantity of soluble sugars in nectar was evaluated using spectrophotometer (Roberts, 1977; 1979), with five flowers collected at each two hours, at from $0700 \mathrm{~h}$ to $1500 \mathrm{~h}$ in four days in all treatments. To estimate the total carbohydrates quantity per flower the data of soluble sugar quantity in the nectar applying the following formula (Dafni, 1992) were used:

spectrophotometer identification x $50 \mu \mathrm{g}$ glucose $/ \mathrm{mL}$

$\mathrm{X}_{1}$

$=$

pattern reading in the spectrophotometer

$\mathrm{X}_{2}=\mathrm{X}_{1} \mathrm{x} \mathrm{mL}$ of distilled water utilized

$\mathrm{X}_{3}=\frac{\mathrm{X}_{2}}{\text { Flowers number }}=\begin{gathered}\text { carbohydrates } \\ \text { quantity/ flower } \\ (\mu \mathrm{g})\end{gathered}$

Glucose was quantified by spectrophotometer using the kit GLUCOSE PAP (Labtest) in all repetitions of three treatments in the same samples in which soluble sugars were estimated.

The concentration of total soluble sugars and the quantity of water present in the nectar were measured as sucrose equivalent ( $\%$ total solid) in free treatment and in treatment covered with honeybees during the day (at 0800h, 1000h, $1200 \mathrm{~h}, 1400 \mathrm{~h}$ and $1600 \mathrm{~h})$. A. mellifera worker honeybees visiting the soybean flowers were captured and sacrificed and the honey crop content was deposited directly in a hand-held refratometer that allowed measuring the concentration from zero to $32 \%$ Brix.

The volume of nectar/flower was obtained through the sugar quantity per flower and of the average of concentration of total soluble sugar in nectar in uncovered area and in one covered with honeybees (Dafni, 1992):

$$
\begin{aligned}
& \text { Volume }=\frac{\text { Quantity of sugar/flower }(\mu \mathrm{g})}{\text { in }(\mu \mathrm{mL} / \text { flower })} \\
& \text { Concentration of sugar/flower }(\mathrm{g} / \mathrm{m})
\end{aligned}
$$

The osmophore test was carried out according to the method of Vogel (1962) mentioned by Vogel (1983). The smell test was carried out after packing 20 flowers during one hour to eventual smell concentration and evaluated by three people and one quick opening. The visit frequency by insects in the areas, during the day was obtained per counting of the insects through the observation during 10 minutes at each time from $0700 \mathrm{~h}$ until 
$1700 \mathrm{~h}$ in four repetitions in uncovered area and covered with honeybees. The most frequent insects were photographed, filmed and collected with help of an entomologic net. Later, the insects were identified and the collection was organized.

The nectar and/or pollen collection time was measured with a chronometer, accompanying the bee activity. The time in the flower and the visits in one minute were measured too. To observe the collection type (nectar and/or pollen) performed by $A$. mellifera, five honeybees were collected an each hour during the day (from $0700 \mathrm{~h}$ to $1500 \mathrm{~h}$ ) and the contents of its corbicula and honey crop were evaluated. The data were statistically analyzed using a completely randomized design. After the variance analyzes, the averages were compared, using the Tukey's test (Pimentel Gomes, 1990). The study of the relation between the variables was carried out through the partial correlation and multiple regressions (SAS Institute, 1998). The data which did not present normal distribution were analyzed through the methodology of generalized linear models (McCulloch and Scarle, 2001).

\section{RESULTS}

Table 1 presents the results of the anthesis period, for the three treatments to which soybean flowers were submitted. Anthesis was higher $(\mathrm{P}<0.0001)$ in flowers of the treatment covered without honeybees than in the other treatments which did not present difference among themselves $(\mathrm{P}>0.05)$.

Table 1 -F values with respective probability $(\mathrm{P})$ coefficient of variation $(\mathrm{CV} \%)$ and the averages of the anthesis period, in hours, in soybean flower Glycine max, variety BRS -133

\begin{tabular}{l|l}
\hline Variation source & Anthesis period in hours \\
\hline \hline Treatments & $12.07 \quad \mathrm{P}=0.0001$ \\
\hline $\mathrm{CV} \%$ & 33.08 \\
\hline \hline Uncovered area & $59.85 \quad \mathrm{a}^{*}( \pm 3.14)$ \\
\hline Covered area with honeybees & $68.80 \mathrm{a} \quad( \pm 3.44)$ \\
\hline Covered area without honeybees & $82.82 \quad \mathrm{~b}( \pm 3.48)$ \\
\hline \hline
\end{tabular}

*Averages followed by different small letters are different by Tukey’s test $(\mathrm{P}<0.05)$

Stigma of soybean flowers were more receptive in treatment covered with honeybees $(\mathrm{P}=0.0021)$. Considering if the flower was receptive or not, independent of the score, the stigma receptivity was $72.0 \pm 45.0 \%$ in uncovered area, $66.7 \pm 47.0 \%$ in covered with honeybees and $87.3 \pm 33.0 \%$, in the one covered without honeybees. These results were significantly different $(\mathrm{P}=0.0021)$ and there was significant difference among the times $(\mathrm{P}=0.0001)$. The stigma receptivity in soybean flowers Glycine max, during the day can be observed in the Fig. 3.

From the figure, it could be observed that the maximum intersection point, calculated from the curve equation derivation, showing that at 10:42 was the time of the largest receptivity. The statistical analysis results of the pollen grains viability retired of the plants are presented on Table 2. There was no significant difference $(\mathrm{P}>0.05)$ among the treatments or among the times, neither of the interaction among these variables.

During the flowering period, when the test was performed, the pollen viability was kept high, and the average was $99.86 \pm 0.17 \%$. The pollen grains retired from the honeybees presented high viability and there was no difference $(\mathrm{P}>0.05)$ between the uncovered area and the one with honeybees. The average in uncovered area was $99.95 \pm 0.11 \%$ and, in one with honeybees of $99.94 \% \pm 0.16 \%$.

The microscopic analysis of the pollen grains retired from the corbicula of worker honeybees, visiting soybean flowers, showed no pollen from other species in the analyzed laminas. The abortion percentage in the flowers in five soybean plants in covered area without honeybees was superior $(\mathrm{P}=0.0002)$ to the uncovered area and covered area with honeybees, which were not different $(\mathrm{P}>0.05)$ between them (Table 3$)$.

The total sugar quantity, in $\mu \mathrm{g} /$ flower, extracted from soybean flowers is shown in Table 4. There 
was no difference $(\mathrm{P}>0.05)$ among the treatments, but an increase of $19.83 \%$ and $11.76 \%$ in quantity of total sugar per flower was observed, in uncovered area and covered with honeybees, respectively, in relation to the covered area without honeybees. The average of quantity of total sugar in soybean flowers in all treatments was $14.33 \mu \mathrm{g} /$ flower, and ranged from 5.25 to $42.61 \mu \mathrm{g} / \mathrm{flower}$.

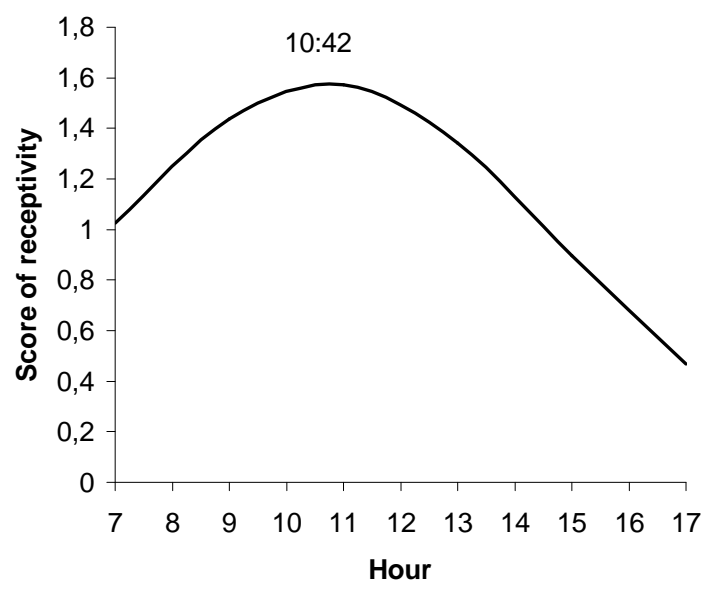

Figure 3 - Regression curve obtained through the equation: Y $\exp ^{(-3.1019+0.663 \times \mathrm{h}-0.0309 \times \mathrm{h} 2)}$ of stigma receptivity (score from 0 to 2) observed in soybean flowers Glycine max, variety BRS-133, from $7 \mathrm{~h} 00$ until $17 \mathrm{~h} 00$, from $18^{\text {th }}$ to $24^{\text {th }}$ January 2001

Table 2 -F value with respective probability $(\mathrm{P})$, coefficient of variation $(\mathrm{CV} \%)$ of the pollen grains percentage of viability in soybean flowers Glycine max variety BRS-133

\begin{tabular}{l|ll}
\hline Variation source & \multicolumn{2}{|l}{ Pollen grains viability percentage } \\
\hline \hline Treatment & 0.54 & $\mathrm{P}=0.5876$ \\
\hline $\mathrm{CV} \%$ & 0.17 & \\
\hline \hline Uncovered area & 99.82 & $( \pm 0.04)$ \\
\hline Covered area with honeybees & 99.87 & $( \pm 0.04)$ \\
\hline Covered area without honeybees & 99.88 & $( \pm 0.04)$ \\
\hline \hline
\end{tabular}

Table 3 -F values with respective probability $(\mathrm{P})$, coefficient of variation $(\mathrm{CV} \%)$ of the percentage of abortion flowers in Glycine max, variety BRS-133

\begin{tabular}{l|ll}
\hline \hline Variation source & Abortion percentage of flowers \\
\hline \hline Treatment & \multicolumn{1}{c}{$10.30 \quad \mathrm{P}=0.0002$} \\
\hline $\mathrm{CV} \%$ & \multicolumn{2}{|c}{24.90} \\
\hline Uncovered area & $52.66 \quad \mathrm{a}^{*}( \pm 2.79)$ \\
\hline Covered area with honeybees & $53.95 \quad \mathrm{a} \quad( \pm 2.79)$ \\
\hline Covered area without honeybees & $82.9 \quad \mathrm{~b}( \pm 6.24)$ \\
\hline \hline
\end{tabular}

*Averages followed by small different letters are different between themselves by Tukey's test $(\mathrm{P}<0.05)$ 
Also, there was no difference $(\mathrm{P}>0.05)$ between the treatments in relation to quantity of glucose in soybean flowers. The average was $3.61 \mu \mathrm{g} /$ flower, and ranged from 1.05 to $17.8 \mu \mathrm{g} /$ flower (Table 4 ).
Table 5 shows the sugar concentration (total solids -brix) of honey crop content of worker honeybees captured foraging the soybean flowers.

Table 4 - F values with respective probability (P), and coefficient of variation (CV\%) of quantity of total sugar and glucose ( $\mu \mathrm{g} /$ flower) of soybean Glycine max, variety BRS-133

\begin{tabular}{l|l|l}
\hline \hline Variation source & Total sugar $(\mu$ g/flower $)$ & glucose $(\mu \mathrm{g} / \mathrm{flower})$ \\
\hline \hline Treatment & $1.50 \mathrm{P}=0.2310$ & $0.08 \mathrm{P}=0.9190$ \\
\hline CV \% & 40.78 & 80.17 \\
\hline \hline Uncovered area & $15.73 \quad( \pm 1.19)$ & $3.42( \pm 0.59)$ \\
\hline Covered area with honeybees & $14.29 \quad( \pm 1.25)$ & $3.70( \pm 0.62)$ \\
\hline Covered area without honeybees & $12.61 \quad( \pm 1.32)$ & $3.76( \pm 0.66)$ \\
\hline \hline
\end{tabular}

Table 5 - F values with respective probability (P), coefficient of variation (VC\%) and the soluble sugar concentration in BRIX of the honey crop content of the worker honeybees (Apis mellifera) foragers in soybean Glycine max flowers, variety BRS-133

\begin{tabular}{l|l}
\hline Variation source & BRIX \\
\hline Treatment & $5.08 \quad \mathrm{P}=0.0265$ \\
\hline Time & $2.26 \quad \mathrm{P}=0.0237$ \\
\hline Treatment x time & $1.06 \quad \mathrm{P}=0.3982$ \\
\hline CV $\%$ & 9.76 \\
\hline \hline Uncovered area & $21.33 \quad \mathrm{~b} *( \pm 0.22)$ \\
\hline Covered area with honeybees & $22.33 \quad \mathrm{a} \quad( \pm 0.38)$ \\
\hline \hline $07: 00$ & $19.08 \quad \mathrm{~b}( \pm 1.62)$ \\
\hline $08: 00$ & $20.67 \quad \mathrm{ab}( \pm 2.39)$ \\
\hline $09: 00$ & $21.42 \quad \mathrm{ab}( \pm 1.78)$ \\
\hline $10: 00$ & $21.83 \quad \mathrm{ab}( \pm 3.01)$ \\
\hline $11: 00$ & $21.41 \quad \mathrm{ab}( \pm 1.98)$ \\
\hline $12: 00$ & 22.08 a $( \pm 2.75)$ \\
\hline $13: 00$ & $22.92 \quad \mathrm{a} \quad( \pm 1.98)$ \\
\hline $14: 00$ & $22.16 \quad \mathrm{a} \quad( \pm 1.90)$ \\
\hline $15: 00$ & $21.91 \quad \mathrm{a} \quad( \pm 2.15)$ \\
\hline $16: 00$ & $22.33 \quad \mathrm{a} \quad( \pm 1.44)$ \\
\hline \hline
\end{tabular}

*Averages followed by small different letters are different between themselves by Tukey's test $(\mathrm{P}<0.05)$

The total soluble sugar concentrations were significantly different $(\mathrm{P}=0.0265)$ between treatments (Table 5). Also, there were differences among the timetable $(\mathrm{P}=0.0237)$, but no difference $(\mathrm{P}>0.05)$ was obtained in interaction of treatment and timetable. The average variation of sugar concentration in nectar extracted from honey crop during the day is shown in Fig. 4. The nectar volume in soybean flower was not different $(\mathrm{P}>0.05)$ between uncovered area and covered area with honeybees and the average was $0.072 \pm 0.04$ $\mu \mathrm{L} /$ flower.

No smell was detected in the soybean flowers, when submitted to the smell test.

In total frequency evaluation of the insects from the soybean flowers, 228 insects were observed in uncovered area, and 217 A. mellifera (95.18\%), eight Lepidoptera $(3.51 \%)$ and three Meliponinae (1.32\%). In covered area with honeybees, $69 A$. mellifera were observed. 
The results of the insect frequency showed significant difference $(\mathrm{P}=0.0001)$. The average number of honeybees observed in the first 10 minutes of each hour, from 7:00 to $16: 00 \mathrm{~h}$ in uncovered area was $5.43 \pm 5.90$ and in covered area with honeybees was $2.30 \pm 2.48$.
During the flowering, the insect collect was performed and the following species were identified, besides A. mellifera:

Trigona fuscipennis Friese, 1900

Exomalopsis subtilis Timberlake, 1980

Exomalopsis analis Spinola, 1853

Exomalopsis tomentosa Friese, 1899

Exomalopsis ypirangensis Schrottky, 1910.

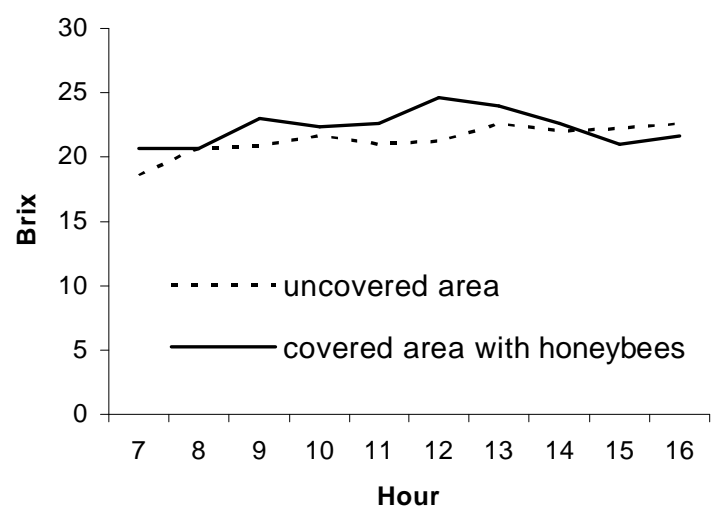

Figure 4 - Sugar quantity in Brix, measured from the content of the honey crop of the captured honeybees, foraging the soybean flowers Glycine max, variety BRS-133.

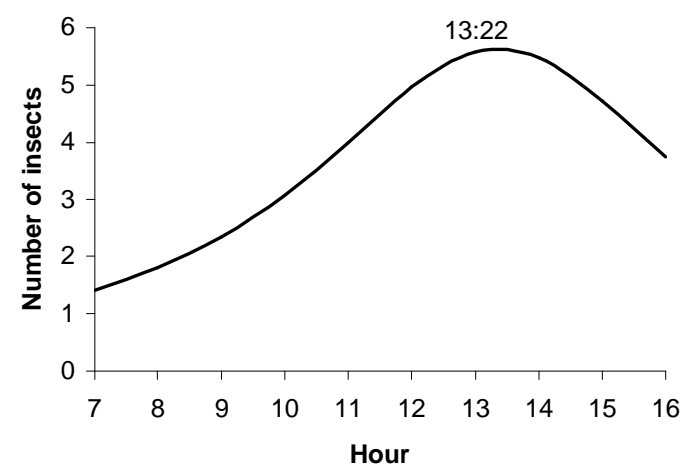

Figure 5 - Regression curve obtained through the equation $\mathrm{Y}=\exp ^{(2.4997-0.3475 \times \mathrm{h}+0.013 \times \mathrm{h} 2)}$ of insect numbers in uncovered area, visiting soybean flowers Glycine max, variety BRS-133

The insects started visits between 7:00 and 8:00 $\mathrm{h}$ and the butterflies were the first. Before 9:00 h, honeybees were not observed with pollen in its corbicula. After 17:00 h, few insects were observed visiting flowers.

Fig. 5 shows the visit frequency during the day in uncovered area. Occurrence of a higher number of insects at 13:22, value calculated through the derivation of the equation presented in this figure was observed.

In uncovered area, the time of nectar collection was $2.55 \pm 0.07$ seconds; this time was shorter $(\mathrm{P}=0.0039)$ than the time of $2.87 \pm 0.08$ seconds, observed in covered area with honeybees. In cages 
of this treatment, it was not found worker honeybees collecting exclusively pollen were not found. In uncovered area the average time of pollen collection was $4.15 \pm 0.16$ seconds. $A$. mellifera visited 12.3 flowers/minute in uncovered area, in average.

The behavior to this kind of collection observed in the honeybee $A$. mellifera foraging in soybean flowers, through the pollen content in its honey crop and of the pollen quantity in its corbicula is presented on Figs. 6 and 7.

\section{DISCUSSION}

The longest period of anthesis found in covered area without honeybees suggested that the flowers not visited by insects remained opened in longer period than the covered area with honeybees (20.4\%) and in uncovered area (38.4). This fact suggested that the flowers waited the pollinator agent and performed the auto-pollination only as the last recourse. The values found in this research were inferior to the ones obtained by Kotaka et al 2000 for canola flowers (Brassica napus e $B$. campestris, Cruciferae) that found a period $77.5 \%$ longer in covered area without honeybees, and by Vieira (2001) that found an anthesis period $43.5 \%$ longer in covered area without honeybees, related to the one discovered in siratro (Macroptilium atropurpureum Urb.). It seemed that there was an agreement that the anthesis period was always longer in treatments in which the honeybees were prevented to perform the visit.



Figure 6 - Dispersion worker percentage found with nectar in content of honey crop foraging flowers of soybean Glycine max, variety BRS-133

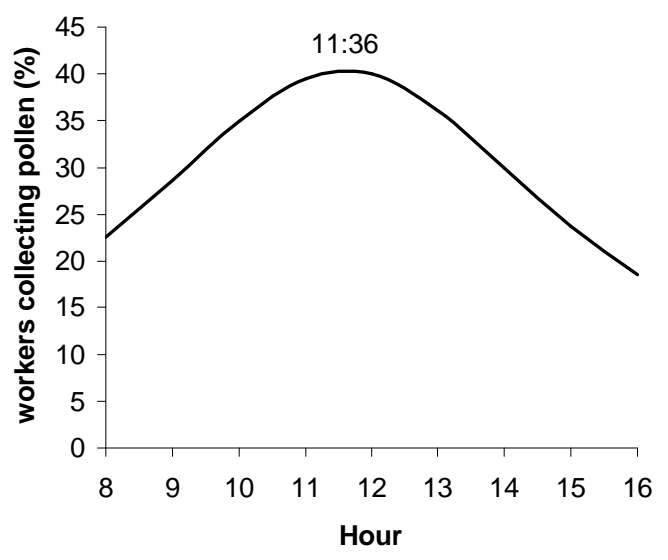

Figure 7 - Regression curve obtained through the equation $Y=\exp ^{(0.2266-0.0348 \times \mathrm{h}+0.0015 \times \mathrm{h} 2)}$ of the number of worker honeybees collecting pollen, in uncovered area, found visiting the soybean Glycine max flowers, variety BRS-133. 
There was no significant difference $(\mathrm{P}>0.05)$ in anthesis period in soybean flowers between uncovered area and covered area with honeybees. This showed that the covering effect did no interfere in anthesis period and suggested that the honeybee A. mellifera satisfied the necessity of cross-pollination of this variety of soybean.

The biggest stigma receptivity $(87.3 \% \pm 33.0 \%)$ in flowers of covered area without honeybees related to the other treatments could be a consequence of the lack of fertilization and, thus, the stigma remained receptive for much more time, waiting the pollinator agent. Vieira (2001) tested the receptivity in the flowers of $M$. atropurpureum Urb and observed that $76.9 \%$ of the buds and 91.95 of the opened flowers were with the stigma receptive to the pollen grains, Kotaka et al(2000), in canola culture (B. napus and B. campestris, Cruciferae), observed a receptivity of $91.1 \%$ of the opened flowers.

The high viability of the pollen grains in all treatments, $99.6+0.02 \%$ in mean, suggested that these ones did not depend on the conditions in which the flowers were imposts, being always ready to perform its role. Vieira (2001) found $100 \%$ of viability in pollen grains in $M$. atropurpureum.

The biggest abortion percentage in flowers observed in covered area without honeybees (82.91 \pm 6.245$)$ showed that, despite of the soybean was considered autogamic by the researchers like Morse and Cartter (1937) and Rubis (1970), it probably has a mechanism of genetic incompatibility to avoid $100 \%$ of auto fecundation, as observed recently to the plants Brassica by Gaude and Cabrillac (2001). Shaik and Probst (1958) observed high indexes of abortion in soybean, which varied from $43 \%$ to $87 \%$, depending on the variety and Free (1993) observed that many varieties presented indexes superior to $75 \%$ of abortion.

Sugar concentration measured as total solids, showed uniform, different of the results obtained by Sheepard et al (1978) that observed big variations in these concentrations and attributed these differences to the variation in the soil composition and other environmental conditions, like precipitation. The biggest uniformity of the data found in this experiment showed that it could be due to the good uniformity of the evaluated samples.

The average volume of nectar found in uncovered area and in covered area with honeybees was
$0.072 \pm 0.04 \mu \mathrm{L} /$ flower. These values were similar to the ones found by Severson and Erickson (1984) from 0.022 to $0.127 \mu \mathrm{L} /$ flower, but they were inferior from 0.2 to $0.5 \mu \mathrm{L} /$ flower observed by Erickson, (1984).

It was not possible to identify smell in the flowers; as in the test of the osmophore did not show odour glands. According to Free (1993), the honeybees choose its source of food, in function of the energetic balance between the energy dispensed to collect food and the net gain. The smell would one attribute more of the flowers to attract the insects. Robacker et al (1982) reported that the attractiveness was linked to several environmental factors and the effects interfered on the flower characteristics.

A. mellifera honeybees were the most frequent insect and visited soybean flowers intensively. The quantity of $A$. mellifera honeybees found visiting the flowers showed the potential of the food resources that this variety had available to the insects through the flowers. Piper and Morse (1923) Jaycox (1970) Erickson (1975) also observed a large number of honeybees visiting fields with many varieties of soybean.

Present work showed that the honeybees visited the soybean flowers mainly for the nectar collection and, at certain times, the collection of pollen and nectar was intense. Rarely, the honeybee collected only pollen. These results were according to the ones found by Jaycox (1970) that observed the nectar and pollen collection, but they disagree with Morse and Cartter (1937), who observed that the honeybee visited the soybean, mainly for the pollen collection.

Even with the behavior destined to the nectar collection, A. mellifera honeybees were efficient as pollinators, as observed by Free (1993) that the honeybees did not need to be pollen collectors to be efficient as pollinators, they could collect only nectar.

The longest time spent in nectar collection found in covered area with honeybees could be due to the smaller competition. This fact was corroborated by the smaller frequency of visitation. Another reason for this could be the interference that the cage caused in activity of hoarding by the honeybees.

The fidelity of the honeybees to the soybean showed that the flowers of this species satisfied the nutritional requirements, and it was not necessary to visit other species, even with other blossoming and attractive as the sunflower (Helianthus annuus). 
The attractiveness, availability and the benefits that soybean flowers have seems to be conditioned to the several varieties, climatic conditions and type of soil. The flowers showed alterations in biology for different treatments, mainly when they were exposed to the honeybees. The flowers increased their anthesis period, the stigmas became more receptive and the abortion index increased, when they did not receive the pollinator insect visit. In the conditions in which the BRS-133 variety of soybean was evaluated, it showed attractive, making available food resources to the insects, mainly to A. mellifera that was efficient in the pollination work.

\section{ACKNOWLEDGEMENT}

We are grateful to Conselho Nacional de Desenvolvimento Científico e Tecnológico (CNPq) process no. 479868/01-8 for financial support and Coordenação de Aperfeiçoamento Pessoal de Nível Superior (CAPES) for the grant of scholarships.

\section{RESUMO}

Este experimento teve como objetivos avaliar a polinização realizada por abelhas Apis mellifera, estudar a biologia floral e observar o comportamento de coleta nas flores de soja (Glycine $\max$ L. Merril), variedade BRS-133 plantadas na região de Maringá-PR. Os tratamentos constituíram de áreas demarcadas de livre visitação por insetos, áreas cobertas por gaiolas, com uma colônia de abelhas (A. mellifera) no seu interior e plantas também cobertas por gaiola que impedia a visitação por insetos. Todas as áreas possuíam $24 \mathrm{~m}^{2}$ (4 m x $\left.6 \mathrm{~m}\right)$. As flores de soja permaneceram abertas por um tempo maior $(82,82 \pm 3,48$ horas) no tratamento coberto sem abelhas. O estigma das flores também se mostrou mais receptivo $(\mathrm{P}=0,0021)$ no tratamento coberto sem abelhas $(87,3 \pm 33 \%)$ e, às $10 \mathrm{~h} 42 \mathrm{~min}$, foi o horário de maior receptividade. $\mathrm{O}$ pólen se manteve viável em todos tratamentos, a média foi de $99,60 \pm 0,02 \%$, não apresentado diferenças entre tratamentos. $\mathrm{O}$ teste de fidelidade demonstrou que as abelhas A. mellifera foram $100 \%$ fiéis às flores de soja. A porcentagem de aborto das flores foi de $82,91 \%$ no tratamento sem abelhas e este resultado foi superior $(\mathrm{P}=0,0002)$ aos $52,66 \%$ e $53,95 \%$ dos tratamentos livre e coberto com abelhas, respectivamente. As quantidades médias de açúcar total e de glicose medidas no néctar das flores foram, respectivamente, de 14,33 $\pm 0,96 \mu \mathrm{g} /$ flor e de 3,61 $\pm 0,36 \mu \mathrm{g} /$ flor, não apresentando diferenças ( $\mathrm{P}>0,05)$ entre os tratamentos. Os sólidos totais, medidos através do refratômetro manual foram de $21,33 \pm 0,22 \%$ no tratamento livre e de $22,33 \pm$ $0,38 \%$ no tratamento coberto com abelhas e estes resultados diferiram entre si $(\mathrm{P}=0,0001)$. A quantidade de néctar nas flores foram similares entre os tratamentos, sendo que o volume médio de néctar/flor foi $0,072 \pm 0,04 \mu \mathrm{L} /$ flor. As abelhas A. mellifera foram os insetos mais freqüentes $(95,18 \%)$. Outros insetos observados foram os lepidópteros $(3,51 \%)$ e outras abelhas $(1,32 \%)$, no tratamento livre. Neste tratamento, o tempo de coleta para néctar foi de 2,55 $\pm 0,07$ segundos que foi menor $(\mathrm{P}=0,0039)$ que o tempo de $2,87 \pm 0,08$ segundos, observado no tratamento coberto com abelhas. O comportamento para o tipo de coleta observado nas abelhas A. mellifera mostrou que as coletoras de néctar não apresentaram um padrão, mas para pólen, o horário de pico das coletoras foi às 11h36min. As flores de soja se mostraram sensíveis aos tratamentos, revelando alterações na sua biologia quando foram expostas ou não às abelhas.

\section{REFERENCES}

Dafni, A. (1992), Pollination ecology: a practical ecology. Oxford : Oxford University Press.

Embrapa. Produção Mundial da soja, safra 2000/2001. http://www.cnpso.embrapa.br/tabsoj1.htm, (15/02/2001).

Erickson, E. H. (1975), Effect of honey bees on yield of three soybean cultivars. Crop Science, 15 : (1), 84-86.

Erickson, E. H. (1984), Soybean pollination and honey production a research progress report. American Bee Journal, 124, 775-779.

Erickson, E. H. and Garment, M. B. (1979), Soya-bean flowers: nectary ultra structure, nectar guides, and orientation on the flower by foraging honeybees. Journal of Apicultural Research, 18 : (1), 1-11.

Free, J. B. (1993), Insect pollination of crops. New York : Academic Press.

Gaude, T. and Cabrillac, D. (2001), Self-incompatibility in flowering plants: the Brassica model. C. R. Acad. Sci., 324, 537-542. 
IBGE. Sistema IBGE de recuperação automática. Acervo completo. (2000), Levantamento sistemático da produção agrícola. http://www.ibge.org.br.

Jaycox, E. R. (1970), Ecological relationships between honey bees and soybean. I. Introduction. American Bee Journal, 110, 306-307, 343-345, 383-385.

King, J. R. (1960), The peroxidase reaction as an indicator of pollen viability. Stain Technology, 36, 225-227.

Kotaka, C. S.; Mitsui, M. H. and Vieira, R. E. et al. (2000), Polinização por abelhas (Hymenoptera, Apoidea) em cultura de canola (Brassica napus e $B$. campestris, Cruciferae) na Região de Maringá, PR. Trabalho apresentado na $37^{\mathrm{a}}$ Reunião Anual da Sociedade Brasileira de Zootecnia, Viçosa, MG, Brasil.

Mason, C. E. (1979), Honey bee foraging activity on soybeans in Dellaware. In: International Symposium on Pollination, 4., Maryland, USA. Proccedings...

McCulloch, C. E. and Scarle, S. R. (2001), Generalized, Linear, and mixed models, New York : Wiley Inters Science Publication. 321 pp.

McGregor, S. E. (1976), Insect pollination of cultivated crop plants. Washington: USDA. (Agriculture Handbook).

Morse, R. A. and Cartter, J. L. (1937), Improvement in soybeans. Yb. U. S. Dep. Agric., 1154-1159.

Morse, R. A. and Calderone, N. W. (2000), The value of honey bees as pollinators of U.S. crops in 2000. Bee Culture, 132 : (3), 1-15.

Pimentel Gomes, F. (1990), Curso de estatística experimental. Piracicaba : Nobel.

Piper, C. V. and Morse, W. J. (1923), The soybean. New York : McGraw Hill.

Robacker, D. C.; Flottum, P. K. And Sammataro, D. et al. (1982), Why soybean attract honey bees? American Bee Journal, 122 : (7), 481-485.

Roberts, R. B. (1977), Method for absorbing nectar sugar produced by plants and harvested by insects. Journal of New York Entomological Society, 85 : (4), 197.

Roberts, R. B. (1979), Spectrophotometric analysis of sugars produced by plants and harvested by insects. Journal of Apicultural Research, 18 : (3), 191-195.

Rubis, D. D. (1970), Breeding insect pollinated crops. Arkansas Agricultural Extension Service, 127, 19-24.

Sas Institute (1998), User's guide. Carry, NC: SAS Institute, 1985.

Severson, D. W. and Erickson Jr., E. H. (1984), Quantitative and qualitative variation in floral nectar of soybean cultivars in Southeastern Missouri. Environmental Entomology, 13 : (4), 1091-1096.

Shaik, P. H. and Probst, A. H. (1958), Effects of some environmental factors on flower production and reproductive efficiency in soybeans. Agronomic Journal, 50, 192-197.
Sheepard, W. S.; Jaycox, E. R. and Parise, S. G. (1978), Selection and management of honey bees for pollination of soybean. In: International Symposium on Pollination, 4., University of Maryland College Park, Maryland, USA. Proccedings... 1, 123-130.

Toledo, V. A. A. (1997), Estudo comparativo de produção de cera e geléia real em colônias de abelhas Apis mellifera africanizadas cárnicas, italianas e seus híbridos. Jaboticabal, SP: UNESP, 1997. 196f. Tese (Doutorado em Zootecnia) Universidade Estadual Paulista - Campus de Jaboticabal.

Vieira R. E. (2001), Biologia floral e polinização por abelhas em siratro (Macroptilium atropurpureum Urb.). Maringá-PR : UEM, 2001. 10p. Brasil. Trabalho de graduação (graduação em Zootecnia) Universidade Estadual de Maringá.

Vitali, M. J. and Letizio-Machado, V. L. (1995), Entomofauna visitante das flores de Tabebuia chrysotricha (Mart.) Standl. (Bignoniaceae). Anais da Sociedade Entomológica do Brasil, 24 : (1), 77-88.

Vogel, S. (1983), Ecophysiology of zoophilic pollination. Physiological Plant Ecology, 3, 560-612.

Wolff, L. F. B. (2000), Efeito dos agrotóxicos sobre a apicultura e a polinização de soja, citros e macieira. In: Congresso Brasileiro de Apicultura, 13., Confederação Brasileira de Apicultura. Florianópolis, SC. Brasil. Anais...
Received: April 20, 2004; Revised: July 29, 2004; Accepted: November 30, 2004. 